\title{
PARTISIPASI PEREMPUAN DALAM PEMILIHAN GUBERNUR PROVINSI LAMPUNG TAHUN 2008
}

\author{
Yuswanto \\ Fakultas Hukum Universitas Lampung
}

\begin{abstract}
Lampung governor election on 2008 executed under article 233 (2) of act Number 32/2004 cencerning local government, on the other hand its implementation process is referred to act number 12 / 2008 concerning second ammendment of act number 32/2004 concerning local government. Governor election invites controversy both theoretically and practically. The research explores merely on the woman participation. Research method applies normative research that using secondary data deriving from primary, secondary and tertiary legal sources. The research shows that in governor election 2008 executed under article 233 (2) act number 32/ 2004 concerning local government and its implementation process based on act number 12/2008, the fact show that from 5,36 milion voters, male voters reached of 2.778 .763 voters, female was 2.587 .978 voters, sehinso the total number was 5.366 .741 voters. In sum, male voters was $51,77 \%$ and female voters was $48,33 \%$ This means that woman participation in governor election was 48,33\% In another word, without woman participation, there is no one candidate can be stipulated as elected candidate.
\end{abstract}

Keywords: governor election, woman participation.

\begin{abstract}
Abstrak
Pemilihan Gubernur (Pilgub) Lampung tahun 2008 dilaksanakan berdasarkan Pasal 233 ayat (2) UndangUndang Nomor 32 Tahun 2004 tentang Pemerintahan Daerah, sedangkan proses pelaksanaan selanj utnya didasarkan pada Undang-Undang Nomor 12 Tahun 2008 tentang Perubahan Kedua UndangUndang Nomor 32 Tahun 2004 Tentang Pemerintahan Daerah. Sebab itu, Pilgub ini menuai pro dan kontra baik dari segi teori maupun praktiknya. Namun demikian, pengkajian ini hanya memfokuskan pada partisipasi perempuannya saja. Metode penelitian yang digunakan adalah jenis penelitian normative, dengan menggunakan bahan hukum primer, sekunder dan tersier. Dari hasil penelitian diperoleh hasil bahwa Pilgub Lampung tahun 2008 dilaksanakan berdasarkan Pasal 233 ayat (2) UndangUndang Nomor 32 Tahun 2004 tentang Pemerintahan Daerah, sedangkan proses pelaksanaan selanjutnya didasarkan pada Undang-Undang Nomor 12 Tahun 2008 tentang Perubahan Kedua UndangUndang Nomor 32 Tahun 2004 Tentang Pemerintahan Daerah. Karena Pilgub ini selenggarakan berdasarkan dua UU sekaligus, sehingga mengakibatkan pro dan kontra. Dari 5,36 juta jiwa pemilih pada Pilgub Lampung 2008 ini, jumlah pemilih laki-laki sebanyak 2.778.763 jiwa, sedangkan perempuan sebanyak 2.587.978 jiwa, sehingga jumlah secara keseluruhan sebanyak 5.366.741 jiwa. Pemilih lakilaki sebesar $51,77 \%$ sedangkan pemilih perempuan sebesar 48,33\% Artinya, keikutsertaan perempuan dalam Pilgub Lampung 2008 ini, sebesar 48,33 \% Dengan demikian, tanpa keikutsertaan perempuan, maka tidak satu pasang calon pun yang akan ditetapkan sebagai calon terpilih.
\end{abstract}

Kata Kunci: Pemilihan Gubernur, Partisipasi Perempuan.

\section{Pendahuluan}

Melihat persentase perempuan yang bersaing dalam pemilu legislatif pada April lalu, 35, 35 persen dari 11.301 total kandidat, orang bisa saja menyimpulkan bahwa hak perempuan untuk berpartisipasi aktif dalam kehidupan politik di Indonesia telah benar-benar dijamin. Untuk soal hak memilih dan dipilih, kesimpulan ini mungkin saja benar. Tetapi perempuan In- donesia masih harus berjuang untuk bisa mempengaruhi kebijakan publik yang berkaitan dengan kehidupan mereka.

Sejumlah organisasi perempuan tengah berusaha mengubah realitas ini dengan menyelenggarakan program pendidikan pemilih yang mengulas bukan hanya faktor politik dan budaya, tetapi juga faktor agama yang mempengaruhi peran politik perempuan. Sejak 1999, 
organisasi-organisasi ini telah melatih kaum perempuan untuk menggunakan hak politik mereka agar bisa meningkatkan kualitas partisipasi mereka dalam politik. Banyak perempuan Indonesia tidak menyadari potensi yang mereka miliki untuk menentukan kualitas demokrasi di negeri ini. Selain itu, mereka pun tak memiliki pengetahuan dan keterampilan untuk menggunakan hak politik mereka dan akhirnya memilih bungkam. Akibatnya, mereka tak bisa terlibat dalam pembuatan legislasi yang mempengaruhi hak-hak mereka dan tak terwakili dengan baik di lembaga-lembaga pengambilan kebijakan. ${ }^{1}$

Kurangnya pengetahuan politik bukan satu-satunya faktor yang mempengaruhi kualitas partisipasi mereka dalam perpolitikan negeri ini, tradisi, adat-istiadat, corak budaya, ajaran agama, dan bahkan kebijakan negara juga turut berperan di dalamnya. ${ }^{2}$ Agama, termasuk Islam, telah digunakan sedemikian rupa untuk melanggengkan pemisahan ruang publik bagi laki-laki dan ruang privat bagi perempuan. Negara termasuk segala kebijakannya tidak selalu berjalan sesuai minat perempuan, dan pasar tidak selalu berjalan berlawanan dengan kepentingan perempuan. Kompleksitas dalam hubungan segitiga ini dapat membawa rintangan bagi perempuan untuk berpartisipasi dalam lingkup politik. Hal ini disebabkan oleh adanya pertimbangan bahwa perempuan tidak mandiri secara ekonomis, oleh karenanya perempuan dianggap tidak layak untuk memperoleh akses pada sumber daya. ${ }^{3}$ Sehingga perempuan akan kehilangan posisi tawar mereka dalam dunia politik. Pelabelan-pelabelan negatif/stereotype yang diberikan kepada perempuan pun menjadi salah satu penyebab posisi perempuan diranah publik seperti terpuruk, dimana salah satu diantaranya

"Partisipasi Perempuan Dalam Politik dan Pemerintahan", Jurnal Perempuan Edisi 34, Peneribit Yayasan J urnal Perempuan dan The Ford Foundation, Jakarta, 2004.

2 Aslim, "Gender dalam Pemikiran Islam Dan Kenyataan Sosial", Jurnal SELAMI IPS, Vol. II, No. 21,Tahun XII, Agustus 2007

3 Fajar Apriani, "Berbagai Pandangan Mengenai Gender Dan Feminisme", Jurnal Sosial-Politika, Vol. 15, No. 1, J uli 2008, hlm. 119-120. posisi dan perannya dibidang politik. ${ }^{4}$ Politik hampir selalu disebut-sebut sebagai domain laki-laki, hingga perempuan dianggap tak pantas untuk berpartisipasi di dalamnya.

Ada tiga aspek yang perlu dijelaskan terlebih dahulu dalam artikel ini. Pertama, kata "partisipasi" dalam Kamus Besar Bahasa Indonesia (KBBI), berarti: (1) prihal turut berperan serta dalam suatu kegiatan; (2) keikutsertaan; dan (3) peran serta. Dengan demikian, berpartisipasi mengandung arti bahwa: (1) melakukan partisipasi; (2) berperan serta (dalam suatu kegiatan); dan (3) ikut serta. Sebagai contoh kalimat yang di dalamnya memuat kata "partisipasi" adalah: seluruh masyarakat harus berpartisipasi dalam menyukseskan pembangunan. Kedua, kata "perempuan" dalam KBBI diartikan sebagai: (1) orang (manusia) yang mempunyai puki, dapat menstruasi, hamil, melahirkan anak, dan menyusui; wanita; (2) istri (bini); dan (3) betina (khusus untuk hewan).

Ketiga, frase "pemilihan gubernur" diartikan sebagai pemilihan kepala daerah/ wakil kepala daerah yang diatur dalam Undang-Undang (UU) Nomor 32 Tahun 2004 tentang Pemerintahan Daerah, UU No. 12/ 2008 tentang Perubahan Kedua Atas UU No. 32/2004, dan Peraturan Pemerintah Nomor 6 Tahun 2005 tentang Pemilihan, Pengesahan Pengangkatan, dan Pemberhentian Kepala Daerah dan Wakil Kepala Daerah. Pasal 1 angka 1 PP No. 6/ 2005, menjelaskan: "Pemilihan Kepala Daerah dan Wakil Kepala Daerah yang selanjutnya disebut pemilihan adalah sarana pelaksanaan kedaulatan rakyat di wilayah provinsi dan/atau kabupaten/kota berdasarkan Pancasila dan UndangUndang Dasar Negara Republik Indonesia Tahun 1945 untuk memilih Kepala Daerah dan Wakil Kepala Daerah", yang telah dirubah dengan PP No. 49/2008 tentang Perubahan Ketiga atas PP No. 6/ 2005.

Perkembangan pemikiran perempuan pada awalnya hanya merupakan seruan moral terus berkembang yang kemudian mulai memasuki ranah politik di mana struktur kebijakan strategis di pemerintahan juga harus diisi oleh

Desak Gde Dwi Arini, "Kesetaraan Gender Dalam Realisasi Undang-Undang No.23 Tahun 2004", Jurnal Kertha Wiaksana, Vol. 16, No. 1, J anuari 2010, hlm. 2. 
kaum perempuan. Gerakan moral tidak membawa perubahan signifikan, karena sering dijadikan alat oleh para penguasa untuk mengabsahkan tujuan pribadi/ kelompoknya. Namun sepertinya, kaum perempuan yang belum paham hal ini, bahkan diantara aktivis pergerakan sekalipun. Oleh karena itu, setiap kali diadakannya "pesta demokrasi" seperti Pemilihan Kepala Daerah didorong adanya pemberdayaan politik perempuan yang memiliki target perubahan paradigma tentang perempuan yang rendah menjadi paradigma yang memberikan peran lebih besar kepada perempuan. Arah pemberdayaan perempuan haruslah memiliki target perubahan yang lebih menekankan pada peran sertanya dalam bidang politik karena hanya dengan pemberdayaan politik perempuan, akan tercipta kesadaran dalam diri para perempuan sekaligus dorongan kearah demokrasi yang lebih baik.

Berdasarkan Pasal 24 ayat (2) UU No. 32/ 2004, "Kepala daerah untuk provinsi disebut gubernur, untuk kabupaten disebut bupati, dan untuk kota disebut walikota". Oleh sebab itu, pemilihan kepala daerah di daerah provinsi disebut pemilihan gubernur (Pilgub), di daerah kabupaten disebut pemilihan bupati (Pilbup), dan di daerah kota disebut pemilihan walikota (Pilwal). Pada tanggal 3 September 2008 ini di Provinsi Lampung diselenggarakan Pilgub, dan di Kabupaten Lampung Utara diselenggarakan Pilbub, yang sama-sama diikuti oleh tujuh pasang calon. Perbedaannya adalah, semua pasangan calon gubernur adalah pria, sedangkan terdapat salah satu pasang calon bupati berjenis kelamin perempuan.

Minimnya calon kepala daerah yang berjenis kelamin perempuan di Provinsi Lampung, bukan berarti bahwa kaum hawa ini terpinggirkan. Pemberdayaan perempuan dan anak telah menunjukkan peningkatan yang tercermin dari kualitas hidup perempuan dan anak itu sendiri. Meski belum merata di semua bidang pembangunan, karier perempuan di Provinsi Lampung cukup maju, baik di pemerintah daerah, DPRD, instansi vertikal, maupun di lembaga sosial masyarakat.

Indonesia yang memiliki keragaman secara geografis, budaya maupun sosial, perempuan
Indonesia pun beragam. Peran perempuan menjadi semakin publik; perempuan kini menikmati kesempatan pendidikan yang sama dengan lakilaki dan merupakan bagian yang signifikan dari tenaga kerja. Perempuan yang bekerja di pelayanan publik hampir mencapai setengahnya, dan sekarang terdapat lebih banyak perempuan yang duduk di parlemen dibandingkan periodeperiode sebelumnya.

Pemerintah Indonesia berkomitmen untuk menjunjung hak-hak perempuan melalui berbagai peraturan hukum dan menunjukkannya dengan menandatangani sejumlah komitmen dan kovenan internasional terkait dengan kesetaraan gender. Sementara Keputusan Presiden yang dikeluarkan tahun 2000 telah memberikan mandat untuk pengarusutamaan gender kepada pemerintah, Kementerian Pemberdayaan Perempuan dan Perlindungan Anak telah membuat rancangan sebuah undang-undang baru tentang kesetaraan gender, yang diharapkan akan diberlakukan tahun 2011. Undang-undang ini akan menggantikan Keputusan Presiden dalam memastikan kebijakan-kebijakan yang sensitive gender supaya diimplementasikan di keseluruhan kementerian dan pemerintahan lokal dan undang-undang ini pun akan memiliki yurisdiksi hukum untuk melakukan hal-hal tersebut sebelumnya. Meskipun demikian, masih terdapat beberapa hambatan bagi keterlibatan perempuan di kehidupan publik (UNDP Indonesia). ${ }^{5}$

Pada Pemilu 2004 yang lalu, terdapat kontroversi mengenai keterwakilan perempuan di lembaga legislatif. Banyak sekali kelompok yang peduli terhadap perempuan ini menuntut keterwakilan tersebut, karena menganggap kemampuan kaum hawa ini sama dengan laki-laki. Membedakan antara perempuan dan laki-laki dalam berpolitik memang tidak pada tempatnya, dan kelompok peduli perempuan ini menganggap membuat dikotomi dalam berpolitik merupakan pelanggaran hak asasi manusia (HAM) yang tertuang dalam UUD 1945.

Pasal 28 I ayat (2) UUD 1945, memuat: "setiap orang berhak bebas dari perlakuan yang bersifat dikriminatif atas dasar apapun dan berhak mendapatkan perlindungan terhadap

\footnotetext{
${ }^{5}$ J urnal Perempuan, op.cit.
} 
perlakuan yang bersifat dikriminatif itu". Meskipun secara gaya bahasa frase "yang bersifat diskriminatif" adalah salah, namun semangat yang terkandung di dalamnya merupakan sesuatu yang mulia. Alasannya, karena kata "diskriminatif" dalam Kamus Besar Bahasa Indonesia berarti bersifat diskriminasi (membedabedakan). Diskriminasi artinya, perbedaan perlakuan terhadap sesama warga negara berdasarkan warna kulit, golongan, suku, ekonomi, agama, dan sebagainya.

Sebagai tindak lanjut dari Pasal 28 I ayat (2) UUD 1945 tersebut, maka Pasal 65 ayat (1) Undang-Undang Nomor 12 Tahun 2003 tentang Pemilihan Umum Anggota Dewan Perwakilan Rakyat, Dewan Perwakilan Daerah, dan Dewan Perwakilan Rakyat Daerah, mengatur bahwa: "setiap partai politik peserta Pemilu dapat mengajukan calon anggota DPR, DPRD Provinsi, dan DPRD kabupaten/kota untuk setiap daerah pemilihan dengan memperhatikan keterwakilan perempuan sekurang-kurangnya 30\%". Kata "dapat" yang terdapat dalam pasal tersebut bisa diartikan dengan berbagai makna, sehingga mengakibatkan keterwakilan perempuan tersebut menjadi tidak mutlak 30\% Dalam Kamus Besar Bahasa Indonesia, kata "dapat" diartikan sebagai: (1) mampu, sanggup, bisa, boleh, mungkin; (2) menerima, memperoleh; (3) ditemukan, tertangkap, dan sebagainya; dan (4) berhasil, tercapai. Dengan demikian, kata "dapat" yang terdapat dalam pasal undang-undang tersebut, artinya boleh "ya" dan boleh juga "tidak".

\section{Permasalahan}

Penelitian ini memfokuskan pada dua permasalahan. Pertama, apakah yang mendasari pelaksanaan Pilgub Lampung tahun 2008 ? Kedua, bagaimana partisipasi perempuan dalam Pilgub Lampung tahun 2008 tersebut?

\section{Metode Penelitian}

Analisis hukum tidak lain dari penyelidikan dan pengkajian menurut ilmu hukum (rechtswetenschap, the science of law). Objek penyelidikan ilmu hukum akan mencakup: 1) hukum positif, yakni hukum yang berlaku; 2) penyelidikan terhadap hukum yang pernah ver- laku; dan 3) penyelidikan terhadap hukum-hukum yang diharapkan berlaku di masa depan.

Metode Penelitian yang dilakukan dalam penelitian ini dengan melakukan penelitian yuridis normatif. Penelitian yuridis normatif/ doktrinal merupakan upaya inventarisasi terhadap hukum positif, penemuan asas-asas dan dasar falsafah hukum positif serta upaya menemukan hukum inconcreto. Penelitian ini dilakukan dengan melihat bagaimanakah norma hukum dalam hubungannya terhadap tatanan normatif berkaitan dengan sinkronisasi hukum peraturan perundangan mengenai partisipasi perempuan dalam Pilgub Lampung 2008 atau yang terkait dengan itu.

Sumber data yang digunakan dalam penelitian ini adalah data sekunder yang terdiri dari bahan hukum primer dan bahan hukum sekunder, yang terkait dengan partisipasi perempuan dalam Pilgub Lampung 2008 atau yang berhubungan dengan itu, baik ditingkat propinsi dan kabupaten. Data sekunder, yaitu data diperoleh melalui studi kepustakaan, terdiri dari bahan hukum primer berupa peraturan perundang-undangan, bahan hukum sekunder juga berupa literatur-literatur, tulisan-tulisan ilmiah yang berkaitan dengan partisipasi perempuan dalam Pilgub Lampung 2008. dan bahan hukum tersier yang berupa kamus, monografi dan lain sebagainya, yang semua diperoleh dari perpustakaan Universitas Lampung, Perpustakaan Pasca Sarjana Fakultas Hukum Universitas Lampung, Perpustakaan pribadi, perpustakaan Daerah Lampung maupun perpustakaan lainnya. Dalam rangka mendapatkan data yang akurat, maka ditempuh langkah, yaitu dengan melakukan studi kepustakaan dengan tekhik yang ditempuh adalah dengan membaca, mempelajari, mengutip, membandingkan dan menghubungkan bahan-bahan hukum dari perundang-undangan dan literature, sehingga menjadi satu kesatuan agar mudah dalam pengolahannya.

Data yang telah diolah kemudian dianalisis secara kualitatif, yaitu memberi arti dan menginterprestasikan setiap data yang telah diolah kemudian diuraikan secara komprehensip dan mendalam dalam bentuk uraian kalimat yang sistematis untuk kemudian ditarik ke- 
simpulan, mengenai partisipasi perempuan dalam Pilgub Lampung 2008.

\section{Hasil Penelitian \\ Dasar Hukum Pelaksanaan Pemilihan Guber- nur Lampung Tahun 2008}

Pemilihan Gubernur/ Wakil Gubernur (Pil-

gub) Provinsi Lampung periode 2009-2014, berdasarkan Keputusan Komisi Pemilihan Umum (KPU) Provinsi Lampung Nomor 119/SK/ KPULPG/TAHUN 2007 tentang Penetapan Tahapan, Program dan J adwal Waktu Penyelengaraan Pemilihan Umum Kepala Daerah dan Wakil Kepala Daerah Provinsi Lampung Tahun 2008, diselenggarakan pada tanggal 3 September 2008. Pertanyaannya adalah: mengapa Pilgub Lampung tersebut dilakukan begitu cepat, sedangkan Keputusan Presiden Nomor 71/M Tahun 2004 tanggal 1 J uni 2004 yang mengesahkan pengangkatan Drs. Sjachroedin Z.P., S.H. sebagai Gubernur Lampung masa jabatan 2004-2009 dan Drs. Syamsurya Ryacudu sebagai Wakil Gubernur Lampung masa jabatan 2004-2009 baru akan berakhir pada tanggal 2 Juni 2009 mendatang? Padahal untuk menjamin siklus kekuasaan yang bersifat teratur diperlukan mekanisme pemilihan umum yang diselenggarakan secara berkala, sehingga demokrasi dapat terjamin, dan pemerintahan yang sungguh-sungguh mengabdi kepada kepentingan seluruh rakyat dapat benar-benar bekerja efektif dan efisien. ${ }^{6}$ Pemilihan Gubernur seharusnya dilaksanakan secara berkala/periodik dalam waktu tertentu sesuai dengan peraturan yang berlaku.

Berdasarkan Pasal 233 ayat (2) UndangUndang Nomor 32 Tahun 2004 tentang Pemerintahan Daerah (UU No. 32/2004), "Kepala daerah yang berakhir masa jabatannya pada bulan Januari 2009 sampai dengan bulan Juli 2009 diselenggarakan pemilihan kepala daerah secara langsung sebagaimana dimaksud dalam Undang-Undang ini pada bulan Desember 2008". Pasal yang tergabung dalam ketentuan peralihan UU No. 32/ 2004 inilah yang dijadikan dasar untuk menyelenggarakan Pilgub Lampung pada tanggal 3 September 2008 tersebut.

6 Jimly Asshiddiqie, "Partai Politik Dan Pemilihan Umum Sebagai Instrumen Demokrasi", Jurnal Konstitusi, Vol. 3, No. 4, Desember 2006, hlm. 10-11.
Ketentuan Pasal 233 ayat (2) ini adalah bertentangan dengan Pasal 28D ayat (1) Undang-Undang Dasar 1945, yakni: "Setiap orang berhak atas pengakuan, perlindungan, dan kepastian hukum yang adil serta perlakuan yang sama di hadapan hukum". Pasal tersebut terutama bertentangan dengan kepastian hukum (principle of legal security) dan perlakuan yang sama di hadapan hukum. Menurut van der Vlies, asas kepastian hukum berkaitan dengan dua aspek. Pertama, asas yang melarang pemerintah membiarkan seseorang berada dalam ketidakpastian mengenai apa yang boleh dan tidak boleh dilakukannya. Kedua, asas ekspektasi yang wajar harus dihormati. Aspek yang kedua ini mewajibkan pemerintah untuk menjalankan asas menanggapi pengharapan yang wajar (principle of meeting raised expectation).

Menurut Indroharto, berpendapat bahwa "suatu aspek dari kepastian hukum harus dirumuskan dengan jelas dan pengertiannya jangan sampai bergantung pada penafsiran seseorang". Hal itu sesuai dengan Pasal 110 ayat (3) UU No. 32/ 2004, yakni: "kepala daerah dan wakil kepala daerah sebagaimana dimaksud pada ayat (1) memegang jabatan selama 5 (lima) tahun terhitung sejak pelantikan dan sesudahnya dapat dipilih kembali dalam jabatan yang sama hanya untu satu kali masa jabatan" . ${ }^{7}$

Berdasarkan ketentuan Pasal 110 ayat (3) Undang-Undang No. 32/2004, meskipun Pilgub dipercepat, namun tidak merugikan "incumbent" untuk menjalankan amanahnya (jabatannya) selama lima tahun. Hal itu sesuai pendapat Indroharto, "bahwa hukum yang berlaku itu yang harus diterapkan dan bahwa keputusan itu tidak dapat diubah yang akan merugikan warga masyarakat yang bersangkutan tanpa sesuatu alasan yang lebih maton". ${ }^{8}$

Meskipun Kepres a quo sayogyanya berlaku hingga 2 J uni 2009, tetapi fakta di lapangan menjadi berbeda. Kepres a quo telah dicabut berdasarkan Kepres No. 49/P Tahun 2008 tertanggal 19 J uni 2008 yang berisi dua hal. Pertama, mengesahkan pemberhentian Drs. Sjachroedin Z.P., S.H. dari jabatan Gubernur Lam-

Indroharto, 1994, Usaha memahami Undang-Undang tentang Peradilan Tata Usaha Negara Buku II, hlm. 159.

$8 \quad$ lbid, hlm. 161 
pung dan Drs. Syamsurya Ryacudu dari jabatan Wakil Gubernur Lampung. Kedua, mengesahkan pengangkatan Drs. Syamsurya Ryacudu sebagai Gubernur Lampung untuk masa jabatan 20042009. Menteri Dalam Negeri (Mendagri) Mardiyanto, telah melantik Drs. Syamsurya Ryacudu menjadi Gubernur Lampung (Gubernur Pengganti) masa jabatan 2004-2009 pada hari Rabu tanggal 3 Juli 2008 bertempat di ruang sidang utama DPRD Provinsi Lampung. Karena Drs. Sjachroedin Z.P., S.H. bukan lagi merupakan Gubernur Lampung, maka calon incumbent (di dalam jabatan) dalam Pilgub Lampung menjadi tidak ada, sebab semua calon tidak terikat (lepas, bebas) dengan jabatan kepala daerah.

Berkaitan dengan kepastian hukum, Pasal 6 ayat (1) huruf i Undang-Undang Nomor 10 Tahun 2004 tentang Pembentukan Peraturan Perundang-Undangan (UU No. 10/2004), mengatur bahwa materi muatan peraturan perundangundangan mengandung asas ketertiban dan kepastian hukum. Maksudnya adalah dengan asas ketertiban dan kepastian hukum, bahwa setiap materi muatan peraturan-perundang harus dapat menimbulkan ketertiban dalam masyarakat melalui jaminan adanya kepastian hukum. Mochtar Kusumaatmadja, berpendapat bahwa daIam analisis terakhir, tujuan pokok dari hukum apabila hendak direduksi pada satu hal saja, adalah ketertiban (order). Ketertiban adalah tujuan pokok dan pertama dari segala hukum. Kebutuhan terhadap ketertiban ini, syarat pokok (fundamental) bagi adanya suatu masyarakat manusia yang teratur.

Menurut Ateng Syafrudin, ${ }^{9}$ berdasarkan asas kepastian hukum, seseorang yang dirugikan dapat dipulihkan haknya dengan empat cara. Pertama, asas kepastian hukum tidak menghalangi penarikan kembali atau perubahan suatu keputusan (baca: ketentuan), apabila sesudah sekian waktu dipaksa oleh perubahan keadaan atau pendapat. Kedua, penarikan kembali atau perubahan juga mungkin apabila keputusan yang menguntungkan didasarkan pada kekeliruan, asal saja kekeliruan itu dapat diketahui oleh yang berkepentingan. Ketiga, pe-

Ateng Syafrudin, 1991, Asas-Asas Pemerintahan Yang Layak Pegangan Bagi Pengabdian Kepala Daerah, Bandung: PT Citra Aditya Bhakti, hlm. 7 narikan kembali atau perubahan dimungkinkan, apabila yang berkepentingan dengan memberikan keterangan yang tidak benar atau tidak lengkap, telah ikut menyebabkan terjadinya keputusan yang keliru. Keempat, penarikan kembali atau perubahan dimungkinkan, apabila syarat-syarat atau ketentuan-ketentuan yang dikaitkan pada suatu keputusan yang menguntungkan tidak ditaati.

Ketentuan Pasal 233 ayat (2) Undang-Undang No. 32/2004 a quo, selain bertentangan dengan asas kepastian hukum, juga bertentangan dengan asas persamaan perlakuan. Asas persaman perlakuan dengan asas kepastian hukum pada dasarnya merupakan asas-asas yang paling fundamental dan paling berakar dalam kesadaran hukum yang bersifat umum. ${ }^{10}$ Asas ini menghendaki bahwa agar kasus-kasus yang sama diperlakukan sama pula, sedangkan kasus yang tidak sama diperlakukan tidak sama sesuai dengan tingkat ketidaksamaannya.

Ateng Syafrudin berpendapat bahwa, berdasarkan asas persamaan (egalite) bahwa halhal yang sama harus diperlakukan sama, di samping sebagai salah satu asas hukum yang paling mendasar dan berakar pada kesadaran hukum, itu merupakan asas yang hidup dan kuat dalam lingkungan administrasi. Asas persamaan ini memaksa pemerintah untuk menjalankan kebijaksanaan, karena tujuan dari aturan-aturan kebijaksanaan menunjukkan perwujudan asas perlakuan yang sama. ${ }^{11}$

Pasal 6 ayat (1) huruf $h$ Undang-Undang No. 10/2004, mengharuskan materi muatan peraturan perundang-undangan mengandung asas kesamaan kedudukan dalam hukum dan pemerintahan. Sesuai dengan penjelasannya, maka maksud asas kesamaan dalam hukum dan pemerintahan adalah bahwa materi muatan peraturan perundang-undangan tidak boleh berisi hal-hal yang bersifat membedakan berdasarkan latar belakang antara lain agama, suku, ras, golongan, gender, atau status sosial. Frase "antara lain" menunjukkan bahwa terdapat alasan pembeda lain selain yang disebutkan itu. Artinya, apapun alasannya bahwa materi muatan peraturan perundang-undangan tidak boleh

10 Indroharto, op.cit. hlm. 163

11 Ateng Syafrudin, op.cit. hlm. 15. 
membuat perbedaan perlakuan dalam hukum dan pemerintahan. Hal ini sejalan dengan pendapat Indroharto bahwa salah satu aspek dari asas persamaan perlakuan adalah larangan diskriminasi, yaitu larangan diadakan pembedaanpembedaan atas dasar ciri-ciri golongan yang tidak relevan.

Selain itu, pemuatan Pasal 233 ayat (2) Undang-Undang No. 32/ 2004 dalam Bab XV Ketentuan Peralihan adalah tidak tepat, baik secara teoritik maupun praktik perundang-undangan. Bagir Manan, berpendapat bahwa "ketentuan peralihan timbul sebagai cara mempertemukan antara asas mengenai akibat kehadiran peraturan baru dengan keadaan sebelum peraturan baru itu berlaku". Secara asas, bahwa ketika peraturan baru diberlakukan, maka semua peraturan lama beserta akibat-akibatnya menjadi tidak berlaku. Akan tetapi, jika asas ini diterapkan tanpa memperhitungkan keadaan yang sudah berlaku, maka akan timbul kekacauan hukum, ketidakpastian hukum, dan kesewenang-wenangan hukum. Oleh sebab itu, untuk mengakomodir akibat berlakunya peraturan baru terhadap peraturan lama, maka diadakanlah peraturan peralihan.

Kekhawatiran Bagi Manan itu terbukti, karena dalam Pasal 239A UU No. 12/2008, bahwa "pada saat undang-undang ini mulai berlaku, semua ketentuan dalam peraturan perundang-undangan yang bertentangan dengan undang-undang ini dinyatakan tidak berlaku". Itulah sebabnya, Pilgub Lampung yang diselenggarakan berdasarkan Undang-Undang No. 32/ 2004, tetapi proses pelaksanaannya didasarkan UU No. 12/2008, sehingga menimbulkan ketidakpastian hukum dan perlakuan tidak sama kepada calon gubernur incumbent. Seharusnya, jika Pilgub didasarkan pada UU No. 32/2004, maka proses pelaksanaannya pun harus berdasarkan undang-undang yang sama, sehingga calon incumbent kedudukannya menjadi jelas.

Berdasarkan logika hukum yang benar, maka tidak boleh mencampuradukkan antara materi muatan dalam "ketentuan mengenai objek yang diatur" dengan materi muatan dalam "ketentuan peralihan". Hal inilah yang terjadi pada Pasal 233 ayat (2) Undang-Undang No. 32/ 2004, seharusnya materi muatan tersebut lebih tepat berada pada "ketentuan obyek yang diatur" dibandingkan dengan "ketentuan peralihan". Alasannya, karena ketentuan Pasal 233 ayat (2) a quo merupakan materi muatan yang seharusnya terdapat dalam "ketentuan obyek yang diatur" dalam UU No. 32/2004, dan bukan merupakan ketentuan yang mempertemukan antara Undang-Undang No. 32/ 2004 sebagai UU yang baru dengan UU No. 22/1999 tentang Pemerintahan Daerah sebagai UU yang lama.

Berpedoman pada lampiran C.4. angka 100 UU No. 10/2004, "ketentuan peralihan" memuat penyesuaian terhadap peraturan perundang-undangan yang sudah ada pada saat peraturan perundang-undangan baru mulai berlaku, agar peraturan perundang-undangan tersebut dapat berjalan lancar dan tidak menimbulkan permasalahan hukum. Jika demikian isi dari "ketentuan peralihan", maka ketentuan yang mengatur waktu diseleng-garakannya pemilihan umum kepala daerah (Pilkada) merupakan materi muatan (isi) dari materi pokok (ketentuan mengenai obyek) yang diatur dalam peraturan perundang-undangan.

Ketentuan yang memerintahkan Pilgub dipercepat tersebut seharusnya bukanlah merupakan materi muatan dari "ketentuan peralihan", melainkan materi muatan dari "ketentuan obyek yang diatur". Selain itu, semakin membuat ketidakpastian hukum adalah karena dasar penyelenggaraan Pilgub tersebut adalah UU No. $32 / 2004$, sedangkan proses penyelenggaraannya berdasarkan ketentuan UU No. 12/2008, seperti yang telah disebutkan sebelumnya. Tumpang tindih pemberlakuan kedua undang-undang ini antara lain disebabkan, karena keduanya tidak bisa membedakan antara materi muatan yang seharusnya diatur dalam "ketentuan objek yang diatur" dan materi muatan yang seharusnya diatur dalam "ketentuan peralihan", maupun materi muatan yang seharusnya diatur dalam "ketentuan penutup". Alasannya, karena materi muatan yang seharusnya diatur dalam materi muatan dalam "ketentuan obyek yang diatur" justru diatur dalam "ketentuan peralihan", dan materi muatan yang seharusnya diatur dalam "keten-tuan peralihan" justru diatur dalam "ketentuan penutup". 


\section{Partisipasi Perempuan Dalam Pemilihan Gu- bernur Lampung 2008}

Dari sejumlah arti partisipasi yang telah diuraikan pada awal tulisan ini, kiranya yang paling tepat untuk mewakili arti yang sesungguhnya berkaitan dengan judul di atas adalah keikutsertaan. Dengan demikian, partisipasi perempuan diartikan menjadi keikutsertaan perempuan dan jika digabung dengan frase Pilgub Lampung 2008, maka kalimat tersebut menjadi "keikutsertaan perempuan pada Pilgub Lampung tahun 2008".

Partisipasi dibedakan dengan eksploitasi yang berarti: (1) pengusahaan, pendayagunaan; dan (2) pemanfaatan untuk keuntungan sendiri, pengisapan, pemerasan. Pada "partisipasi", orang yang ikut berperan serta secara sadar apa yang mereka perbuat atas kendali diri mereka sendiri, sedangkan pada "eksploitasi", orang yang berperan serta tidak sadar bahwa mereka di bawah kendali orang lain. Pada "partisipasi", orang yang ikut berperan serta berkedudukan sejajar dengan orang lain yang tergabung dalam suatu kegiatan, sedangkan pada "eksploitasi", orang yang ikut berperan serta berkedudukan sebagai "alat" (bawahan) orang lain dalam suatu kegiatan. Pada "partisipasi", seseorang bekerja berdasarkan kemauan dan akal sehat mereka sendiri, sedangkan pada "eksploitasi", seseorang tersebut bekerja berdasarkan kemauan dan akal sehat orang lain (pengendali).

Berdasarkan perbedaan arti antara "partisipasi" dan "eksploitasi" tersebut, maka dapat diuji perihal keikutsertaan perempuan dalam Pilgub Lampung tahun 2008 ini. Jika ada sekelompok perempuan yang bekerja secara sadar dan atas kendali mereka sendiri untuk memenangkan satu pasangan Cagub/Cawagub pada Pilgub Lampung 2008 ini, maka mereka disebut "berpartisipasi". Akan tetapi, jika terdapat sekelompok perempuan yang bekerja di bawah kendali orang lain untuk memenangkan satu pasangan calon, maka mereka disebut "dieksploitasi". Karena tidak menutup kemungkinan, ada partai tertentu yang memperkerjakan sekelompok perempuan untuk memenangkan satu pasang calon, sehingga mereka di bawah kendali "elit partai" tersebut dalam bentuk dan sebutan apapun, maka sekelompok perempuan tersebut sedang berada dalam "eksploitasi". Eksploitasi semacam ini seringkali dibungkus dengan ideologi tertentu, sehingga terkesan seperti kegiatan yang "mulia", padahal sebetulnya merupakan kegiatan yang "hina".

Partisipasi dalam sistem politik merupakan tugas yang kompleks. Dengan duduknya perempuan di Legilslatif khususnya DPRDD Kabupaten atau Kota maka perempuan dituntut untuk mampu menyumbangkan pemikiran yang strategis bagi perbaikan nasib dan mampu mengakomodasi kebutuhan perempuan didaerahnya sendiri. Serta mampu menghasilkan kebijakan-kebijakan yang mendukung kearah kemajuan bangsa dan daerah pada khusunya.

Ditetapkannya kuota 30\% dari daftar caIon anggota parlemen untuk perempuan merupakan pencapaian terbaik gerakan perempuan, sekalipun banyak kalangan feminis pesimistis dengan pelaksanaan kuota tersebut. Adanya kuota $30 \%$ bagi perempuan sejalan dengan $\mathrm{Pa}$ sal 4 Konvensi CEDAW yang berbunyi "tindakan affirmatif adalah langkah-langkah khusus sementara yang dilakukan untuk mencapai persamaan kesempatan dan perlakuan anatar lakilaki dan perrempuan". Kebijakan ini dianggap sangat penting guna memberikan kesempatan seluas-luasnya bagi perempuan berkiprah dalam politik. Hal ini juga mempertegas hak-hak politik kaum perempuan. ${ }^{12}$

Partisipasi (keikutsertaan) perempuan pada Pilgub Lampung 2008 terbagi dalam tiga kategori, yaitu: penyelenggara, peserta pemilihan (kandidat), dan para pemilih (masyarakat) umum. Penyelenggara Pilgub Lampung terdiri dari KPUD dan juga Panitia Pengawas. Baik KPUD Provinsi Lampung maupun Panitia Pengawas Pilgub Lampung 2008, terdapat orang yang berjenis kelamin perempuan. Artinya, terdapat partisipasi langsung perempuan pada tataran penyelenggara Pilgub Lampung 2008, yang besarannya sekitar 20 persen dari keseluruhan penyelenggara.

12 Lies Ariany, "Partisipasi Perempuan Di Legislatif Melalui Kuota 30\% Keterwakilan Perempuan Di Provinsi Kalimantan Selatan", Jurnal Konstitusi, Vol. 2, No. 1, J uni 2009, hlm. 50-51. 


\section{Penutup}

Simpulan

Keikutsertaan perempuan sebagai peserta Pilgub Lampung sama sekali tidak ada atau nol persen. Karena dari tujuh pasang calon peserta Pilgub Lampung tersebut, tidak satu pun yang berjenis kelamin perempuan. Karena tidak satu pasang pun dari Cagub/ Cawagub Lampung yang berjenis kelamin perempuan, maka kemenangan mereka itu pasti akan ditentukan oleh keikutsertaan perempuan dalam Pilgub Lampung 2008 ini. Sebab, tanpa keikutsertaan pemilih perempuan, maka sulit bagi pasangan siapapun untuk meraih kemenangan sesuai dengan ketentuan Pasal 107 ayat (1) dan (2) UU No. 12/ 2008. Pertama, pasangan calon kepala daerah dan wakil kepala daerah yang memperoleh suara lebih dari 50 \% jumlah suara sah ditetapkan sebagai pasangan calon terpilih. Kedua, apabila tidak terpenuhi, maka pasangan calon yang memperoleh suara lebih dari $30 \%$ dari jumlah suara sah, pasangan calon yang perolehan suaranya terbesar dinyatakan sebagai pasangan calon terpilih.

Berkaitan dengan keikutsertaan perempuan dalam Pilgub Lampung tahun 2008 ini, maka KPUD Provinsi Lampung telah menetapkan jumlah pemilih sebanyak 5,36 juta jiwa. Hal itu diputuskan dalam rapat pleno yang dihadiri lima anggota KUPD Lampung pada hari Selasa tanggal $15 \mathrm{Juli} 2008$ lalu. Meski hal itu merupakan hasil keputusan rapat pleno, tetapi tidak jelas diterbitkan dalam bentuk produk hukum apa, karena jika tidak diterbitkan dalam bentuk produk hukum tertentu, maka hal itu tidak mempunyai kekuatan mengikat secara hukum. Keputusan rapat pleno hanya mengikat secara internal, keputusan tersebut baru dapat mengikat secara eksternal apabila telah ditetapkan dalam bentuk produk hukum. Diduga masih banyak hasil keputusan rapat pleno KPUD Provinsi
Lampung yang tidak diterbitkan dalam bentuk produk hukum, sehingga tidak mempunyai kekuatan mengikat secara hukum pula. Dari 5.36 juta jiwa pemilih pada Pilgub lampung 2008 ini, jumlah pemilih laki-laki sebanyak $2.778 .763 \mathrm{ji}$ wa, sedangkan perempuan sebanyak 2.587.978 jiwa, sehingga jumlah secara keseluruhan sebanyak 5.366. 741 jiwa.

\section{DAFTAR PUSTAKA}

Apriani, Fajar. "Berbagai Pandangan Mengenai Gender dan Feminisme". Jurnal SosialPolitika, Vol. 15, No. 1, J uli 2008;

Ariany, Lies. "Partisipasi Perempuan di Legislatif melalui Kuota 30\% Keterwakilan Perempuan di Provinsi Kalimantan Selatan". Jurnal Konstitusi, Vol. 2, No. 1, J uni 2009;

Arini, Desak Gde Dwi. "Kesetaraan Gender daIam Realisasi Undang-Undang No.23 Tahun 2004". J urnal Kertha Wiaksana, Vol. 16, No. 1, J anuari 2010;

Aslim. "Gender dalam Pemikiran Islam dan Kenyataan Sosial". J urnal SELAMI IPS, Vol. II, No. 21,Tahun XII, Agustus 2007;

Asshiddiqie, Jimly. "Partai Politik dan Pemilihan Umum sebagai Instrumen Demokrasi". Jurnal Konstitusi, Vol. 3, No. 4, Desember 2006;

Indroharto. 1994. Usaha Memahami Undang-Undang tentang Peradilan Tata Usaha Negara Buku II. J akarta: Tatanusa;

J urnal Perempuan. "Partisipasi Perempuan dalam Politik dan Pemerintahan". Jurnal Perempuan Edisi 34, 2004. Penerbit Yayasan J urnal Perempuan dan The Ford Foundation, J akarta;

Syafrudin, Ateng. 1991. Asas-asas Pemerintahan yang Layak Pegangan bagi Pengabdian Kepala Daerah. Bandung: PT Citra Aditya Bhakti; 